\author{
St udia P hilosophic a \\ Wr a t is l avie n s i \\ vol. XV, fasc. $3(2020)$
}

https://doi.org/10.19195/1895-8001.15.3.5

\author{
MICHAŁ PAWE€ MARKOWSKI \\ ORCID: 0000-0003-2187-0665 \\ University of Illinois, Chicago
}

\title{
Sztuka nie oddaje Widzialnego, ale raczej Widzialne umożliwia
}

\section{Art does not render the Visible; Rather it makes Visible}

\begin{abstract}
In this essay the author examines Klee's famous statement in his Creative Confession (1920), which goes as follows: "Kunst gibt nicht das Sichtbare wieder, sondern macht sichtbar". In conclusion, he argues that it should sound this way: "Art does not render the Visible; rather it makes the Visible possible (it lets the Visible happen)". Art, according to Klee, has the power of giving us the access to the domain of pure potentiality, i.e. of pure ideas, anticipating the sphere of empirical experience - in other words, art anticipates what is real, "given", or "visible". While the traditional art represents, it means ,rends visible", the abstract one (Klee's new art) — makes vision as well as visible possible ("makes visible").
\end{abstract}

Keywords: abstract art, making visible, rending visible, ideas, pure potentiality, creation

1. 17 maja 1920 roku Galerie Neue Kunst Hans Goltz otworzyła w Monachium pierwszą retrospektywną wystawę twórczości Klee. Katalog zawierał opis 38 dzieł olejnych (na płótnie i na szkle), 112 akwarel, 179 rysunków (w tym 26 ilustracji do Kandyda z tym samym numerem), 6 rzeźb gipsowych i 27 grafik ${ }^{1}$. Ogromna wystawa czterdziestojednoletniego artysty, której towarzyszyła pierwsza monografia jego twórczości, Paul Klee: Leben, Werk, Geist Leopolda Zahna, opublikowana w czerwcu 1920. Choć jeszcze parę miesięcy wcześniej Klee nie dostał profesury na

${ }^{1}$ Szczegóły za: The EY Exhibition - Paul Klee: Making Visible, katalog wystawy w Tate Modern (16.10.2013-9.03.2014), Thames\&Hudson 2013. 
stuttgarckiej Akademii (co argumentowano jego „marzycielstwem” i „kobiecością” jego obrazów), to rok 1920 był kluczowy dla percepcji jego sztuki. Walter Benjamin kupuje jego Nowego anioła (Angelus Novus), a w październiku Paul Klee dostaje zaproszenie od Gropiusa, który pisze: „Od roku czekałem na moment, kiedy będę mógł wystosować to zaproszenie”. Od 1921 Klee jest już członkiem Bauhausu.

2. Zanim otwarto wystawę, w 13. tomie berlińskiej „Tribüne der Kunst und der Zeit" Paul Klee opublikował swoje, zamówione dwa lata wcześniej, Twórcze wyznanie (Schöpferische Konfession), które zaczyna się najsłynniejszym bodaj jego zdaniem: „Kunst gibt nicht das Sichtbare wieder, sondern macht sichtbar”. W przekładzie Maurin-Białostockiej: „Sztuka nie odtwarza tego, co człowiek widzi, ale czyni widocznym”2. Angielski przekład brzmi znacznie lepiej: „Art does not reproduce the visible; rather, it makes visible"3. Oba przekłady są dobre, ale coś w nich zgrzyta. Niemieckie ,wiedergeben" ma kilka znaczeń, ale dosłownie i najprościej oznacza „oddać”. Klee nie pisze „darstellt” albo „reproduziert”, czyli nie używa technicznych wyrażeń, do których dziś przywykliśmy, tylko mówi najzwyczajniej: „sztuka nie oddaje”. Nie „nie odtwarza” i nie „nie reprodukuje”, lecz „nie oddaje”. Ale czego nie oddaje? „Das Sichtbare”. „Sztuka nie oddaje Widzialnego”. Widzialne nie dlatego piszę tu wielką literą, że jest tak w języku niemieckim (bo być musi jak w przypadku każdego rzeczownika odsłownego), ale dlatego, że Klee przez to słowo rozumie coś znaczniej więcej niż „to, co człowiek widzi” (jak pisze Maurin-Białostocka). Widzialne jest to, co daje się w ogóle zobaczyć, bo należy do sfery empirycznej, tkwi w uniwersum stworzonym. Nie chodzi więc tylko o to, co człowiek ma przed oczami, ale o to, co człowiek może w ogóle zobaczyć, bo należy to do natury tego, co daje się widzieć, a do natury człowieka, że może to zobaczyć. Używając języka scholastycznego, który nowoczesność odnowiła dzięki Heglowi, należy powiedzieć, że das Sichtbare należy do świata aktualnego, świata, który się już nieodwołalnie stał, w kształcie, jaki przypadł mu w udziale. Od tego właśnie świata, świat stworzonego, sztuka wedle Klee się odwraca, o czym mówi druga część zdania: „ale czyni widzialnym”. Oczywiście nie „czyni widocznym”, nawet nie „uwidacznia”, bo nie chodzi o to, żeby coś wystawić „na widok”, ani nawet o to, żeby cokolwiek zobaczyć. Klee jest tu bardzo, scholastycznie, subtelny. Kiedy mówi, że „sztuka nie oddaje Widzialnego”, to znaczy, że sztuka nie oddaje tego, co uprzednio wzięła, czyli zobaczyła. Mówi, że sztuka nie negocjuje ze światem aktualnym, tym, który został już stworzony, lecz wchodzi w przestrzeń, z której świat widzialny się wyłania. Mówiąc inaczej, sztuka to, co daje się w ogóle zobaczyć, co należy do świata widzialnego, bo stworzonego, umożliwia. Przekład tego zdania powinien więc, jeśli chcielibyśmy zachować pełną dosłowność i wszystkie znaczenia w nim zawarte, brzmieć następująco: ,Sztuka nie oddaje Widzialnego, lecz to, co Widzialne umożliwia".

${ }^{2} \mathrm{P}$. Klee, Wyznanie twórcy, tłum. J. Maurin-Białostocka, [w]: Artyści o sztuce. Od van Gogha do Picassa, E. Grabska, H. Morawska (wyb. i oprac.), Warszawa 1969, s. 272. Dosłownie tytuł brzmi „Wyznanie twórcze”, a nie „Wyznanie twórcy”. Niemiecki tekst: http://de.wikisource.org/wiki/ Sch\%C3\%B6pferische_Konfession:_Paul_Klee [dostęp: 20.09.2020].

${ }^{3}$ P. Klee, Creative Confession, [w:] Creative Confession and Other Writings, London 2013. 
3. Dlaczego zamiast „czyni widocznym” albo „czyni widzialnym” piszę „umożliwia Widzialne”? Sztuka od zawsze, od pierwszym naskalnych malowideł, „czyniła [coś] widocznym", sprawiała, że coś można było zobaczyć tak, a nie inaczej, w tej lub innej perspektywie (samo słowo „perspektywa” oznacza „patrzeć przez, żeby coś zobaczyć"); że coś, czego nie było dotąd widać, można było wreszcie zobaczyć. Tym „uwidacznianiem” sztuka zajmowała się od samego początku i można nawet powiedzieć, że to uwidacznianie należy do istoty sztuki przedstawiającej. Sztuka przedstawia, bo chce, żebyśmy widzieli, żebyśmy w naszym patrzeniu znaleźli nowy aspekt albo żebyśmy wreszcie otworzyli oczy na to, co dotąd nie wchodziło w pole naszego widzenia. W każdym razie sztuka przedstawiająca, którą należy utożsamić z głównym nurtem sztuki zachodniej, umieszcza się, jak artysta stawiający swoje sztalugi, przed światem widzialnym, przed tym, co daje się w ogóle zobaczyć, nawet jeśli nie jest to nic, co w tym momencie znajduje się przed oczami. Klee pisze: „Dawniej przedstawiano w sztuce to, co ludzie widzieli wokół siebie, to, na co chętnie patrzyli, albo co pragnęli oglądać" ${ }^{\text {" T }}$ Teraz chodzi o to, żeby w ogóle na świat się nie oglądać.

4. W tym sensie Klee umieszcza sztukę „W krainie głębszego poznania”, das Land der besseren Erkenntnis ${ }^{5}$, które nie może dotyczyć tego, co „widoczne”. Cóż to za kraina? W trzeciej części swojego pierwszego manifestu Klee robi wyraźną, choć negatywną aluzję do Fausta Goethego (z pierwszej sceny w Pracowni). „Na początku był czyn” („Im Anfang ist wohl die Tat”), ale zaraz spieszy dodać, „ale w nim tkwi idea", tworząc zdanie dokładnie symetryczne do zdania, od którego zaczyna swój manifest. Czyn należy do tego samego porządku empirycznego co Widzialne, natomiast idea należy do nieskończoności, gdyż „nie ma żadnego określonego początku”. „Kraina głębszego poznania” to świat idei, ale rozumiany po heglowsku jako sfera Absolutu. To przeciwstawienie oznacza, że idea nie należy do porządku empirycznego, a więc przedstawialnego. W tym sensie mówienie o przedstawianiu idei nie miałoby żadnego sensu i Klee oczywiście nie należy do żadnego alegorycznego nurtu w sztuce, podobnie jak nie należy do nurtu realistycznego. Idea należy do sfery czystej potencjalności, sprzed jakiejkolwiek aktualizacji, sprzed stworzenia, a więc nie można jest przedstawić, albowiem tylko stworzone jest przedstawialne.

5. W 1916, gdy w Zurychu powstaje dada, a Kafka publikuje Przemiane, Paul Klee zostaje wcielony do rezerw piechoty, a następnie przeniesiony do rezerw lotnictwa niedaleko Monachium. 4 marca w bitwie pod Verdun ginie jego przyjaciel Franz Marc, malarz ekspresjonista, członek założyciel grupy Der Blaue Reiter. W dzienniku Klee, zastanawiając się, co ich różniło, pisze między innymi:

Mój żar jest bardziej jak ogień umarłych lub nienarodzonych. Nic dziwnego, że on znalazł więcej miłości. Jego szlachetna zmysłowość z ciepłem przyciągała do niego wielu ludzi. Był wciąż rzeczywi-

\footnotetext{
${ }^{4}$ P. Klee, Wyznanie twórcy, s. 274.

5 Ibidem, s. 272.

${ }^{6}$ Ibidem, s. 273.
} 
stym członkiem rasy ludzkiej, a nie neutralnym stworzeniem. Pamiętam jego uśmiech, gdy moje oko przeoczało jakieś ziemskie chwile. Sztuka jest jak tworzenie: odnosi się zarówno do ostatniego, jak pierwszego dnia ${ }^{7}$.

Tworzenie tutaj — i wszędzie indziej u Klee — to „Schöpfung”, akt boskiej twórczości, która stwarza z niczego i jest wieczna, niezwiązana z czasem, jak ludzkie majstrowanie przy empirii. I dalej: „Umieszczam się w odległym punkcie wyjścia tworzenia, skąd ustanawiam pewne formuły dla ludzi, zwierząt, roślin, kamieni i żywiołów oraz wszystkich innych wirujących sił"8. I by przypieczętować: „Moje ziemskie oko jest czasami rozproszone. Widzę poprzez najpiękniejsze rzeczy. [...] Sztuka to tworzenie w świecie idei" ". To ostatnie zdanie jest tylko interpretacją, bo Klee pisze: „Kunst ist ideelle Schöpfung”. Nie chodzi o to, że sztuka jest idealnym tworzeniem, ale o to, że jej dziedziną, prawdziwą, są idee.

6. Mamy już niemal wszystkie elementy układanki. Spojrzenie Klee nie jest z tego świata i chyba w ogóle nie jest to spojrzenie, zwłaszcza spojrzenie zmysłowe. Od św. Augustyna i w tradycji neoplatońskiej utrzymuje się podział na oculis corporis, oczy ciała, i oculis mentis, oczy umysłu, które jako jedyne mają dostęp do świata nie-widzialnego czy raczej widzialnego jedynie umysłem. Ten świat widzialny to świat czystej potencjalności, świat ,apriorycznych formul”, świat nieskończonej idei, która istnieje jedynie w umyśle samego Boga. Czytamy w Dzienniku: „Szukam sobie dla siebie miejsca u Boga i jeśli jestem z nim związany, nie mogę sobie wyobrazić, że moi bracia są również związani ze mną; ale to ich sprawa"10. W ten sposób, umieszczając się po stronie Boskiego umysłu, przeskakując wzrokiem nad światem widzialnym (co wywoływało uśmiech na twarzy jego przyjaciela) i szybując „poza biały żar” stworzenia, Klee, dość nieoczekiwanie dla wszystkich jego nowoczesnych wielbicieli, wiąże z sobą na trwałe malarstwo i teologię. Paul Klee i Kazimierz Malewicz to dwa skrzydła anioła abstrakcji, które skutecznie przesłaniają to, co można zobaczyć na ziemi. Używając innej metafory: abstrakcja to świat sprzed narodzin albo po śmierci. Nie przypadkiem Czarny kwadrat Malewicza zawisł najpierw u powały, gdzie umieszczało się tradycyjnie ikonę w ruskim domu, następnie nad jego zwłokami w mieszkaniu, a na końcu, na chwilę tylko, został przez wdowę przyczepiony do grobu artysty.

7. Teraz rozumiemy znacznie lepiej to słynne zdanie. „Sztuka nie oddaje Widzialnego, ale raczej Widzialne umożliwia". Nie oddaje, bo nie wzięła nic ze świata widzialnego, nie interesuje się nim, nie zachwyca, nie poddaje się jego urokowi. Raczej sytuuje się po stronie czystej potencjalności, gdzie kształty jeszcze nie nabrały ostateczności, gdzie wir świata dopiero się zaczyna. Umożliwiać Widzialne, ale go — za żadne skarby — nie oddawać, wedrzeć się w sferę czystej potencjalności,

\footnotetext{
7 P. Klee, Tagebücher 1898-1918. Textkritische Neuedition, W. Kersten (ed.), Stuttgart 1988, s. 402.

${ }^{8}$ Ibidem, s. 400.

${ }^{9}$ Ibidem.

10 Ibidem, s. 402.
} 
w której zaczyna się wieczny akt tworzenia: oto teologiczny sens abstrakcji, bez którego nowoczesność byłaby nie tylko nie do pomyślenia, ale i nie do zrozumienia.

\section{Bibliografia}

Klee P., Creative Confession, [in:] Creative Confession and Other Writings, London 2013.

Klee P., Schöpferische Konfession, https://de.wikisource.org/wiki/Sch\%C3\%B6pferische_Konfession:_Paul_Klee [dostęp: 20.09.2020].

Klee P., Tagebücher 1898-1918. Textkritische Neuedition, W. Kersten (ed.), Stuttgart 1988.

Klee P., Wyznanie twórcy, tłum. J. Maurin-Białostocka, [w:] Artyści o sztuce. Od van Gogha do Picassa, E. Grabska, H. Morawska (wyb. i oprac.), Warszawa 1969. 